\title{
A PRELIMINARY STUDY ON THE ECOLOGY OF THE CORAL REEF \\ OF POMBO ISLAND
}

by

ONO KURNAEN SUMADHIHARGA ${ }^{1)}$

\begin{abstract}
A preliminary study on the ecology of the coral reef of Pombo Island was carried out in 1975. Pombo Island has a characteristic of an atoll and is considered a good habitat for coral and fish, including live-bait fish of commercial importance, Spratelloides delicatulus. Non-planktonic organisms collected consist of 39 species of corals, 56 species of molluscs, 17 species of echinoderms, 130 species of fishes and a number of crustacean species.

Some ecological factors such as bottom condition, turbidity, temperatures, light intensity, and fresh water dilution are described. Population and distribution of corals and coral fishes are discussed.
\end{abstract}

\section{INTRODUCTION}

We must keep in mind that nowhere else than on a coral reef is it possible to find such a dense population in such a small area (VERWEY 1929). Coral reefs become more important in Pombo Island because it provides good habitat for many commercial reef fishes such as lalosi (Caesio spp.) and gosau (Spratelloides delicatulus) and because of its aesthetic values for tourism in the Moluccas. As phrased by JoHANNEs (1970), they are "among the most biologically productive, taxonomically diverse and esthetically celebrated of all communities".

In connection with the programme of marine garden investigation from the Directorate General of Nature Reserves, Department of Agriculture, in the Moluccas, a preliminary study on the ecology of the Pombo Island coral reef was carried out from 30 October to 21 November 1975, by a scientific team from the Ambon Research Station of the National Institute of Oceanology and the Faculty of Fishery of the Bogor University of Agriculture.

Ecological investigation on coral reefs as the most densely populated biotopes may elucidate the influences of biotic and abiotic factors on different biocoenoses and communities (MERGNER \& SCHEER 1974).

${ }_{1}^{1}$ Ambon Research Station, National Institute of Oceanology, Indonesian Institute of Sciences, Ambon, Indonesia. 


\section{ONO KURNAEN SUMADHIHARGA}

The community of Pombo Island is principally that of an atoll reef and considered as a good habitat for coral growth, because Pombo Island is a more or less circular reef far out at sea, rising from very deep water. As originally described by DARWIN, atolls are horseshoe shaped ridge of reefs and island with a lagoon in the centre (ODUM 1971).

The reef of Pombo Island investigated provides data on corals, molluscs, echinoderms, crabs and fishes and some observations of different problems of reef ecology. Such problems include the influence of the nature of the bottom, water turbidity or water exchange, freshwater dilution, temperatures, and light intensity as the important abiotic factors on the coral community and the physiographic zonation of the reef are discussed to give a general idea about the importance of the area as a marine garden.

\section{MATERIAL AND METHODS}

All observations, measurements, and collections of corals, molluscs, echinoderms, Crustacea, and fishes made in this study were within the uppersub-littoral zone between depths of one and six metres by skin-diving and by visual means from a motor-boat.

Transects over typical reef sections were divided into four areas (Fig. 2): Northwest Cross Section (CS 1), Northeast CS (CS 2), Southeast CS (CS 3), and Southwest CS (CS 4).

A convenient quadrate frame was used, assembled from $2 \mathrm{~m}$ long wooden battens. Percentage distribution of corals was calculated from those quadrates at various points in transects.

For generalised representation of the results, coral growth and species distribution especially those of Scleractinia, molluscs, echinoderms, crabs, and coral fishes were sampled and observed by skin-diving and collecting with spear, gillnet, hand lines, and hand operation were made all over the reef and outside the transect areas.

Physical observations in this study included the nature and hardness of the bottom, velocity and direction of current, salinity, temperature, transparency, phosphate, and oxygen contents.

\section{DESCRIPTION OF POMBO ISLAND}

Pombo Island is relatively rich in coral reefs, but over one third of them have been damaged. Coral populations at this island form an atoll which lies in Haruku Strait between latitudes 03³1'15" S and 03³1'55' S and longitudes $128^{\circ} 22^{\prime} 20^{\prime \prime} \mathrm{E}$ and $128^{\circ} 22^{\prime} 47^{\prime \prime}$ E. (Fig. 1).

A lagoon about seven hectares in extent with maximum depth of $22 \mathrm{~m}$ extends along the northwestern part of the island, which is encircled by an exposed reef flat during extreme low tide at about $200-300 \mathrm{~m}$ offshore. 


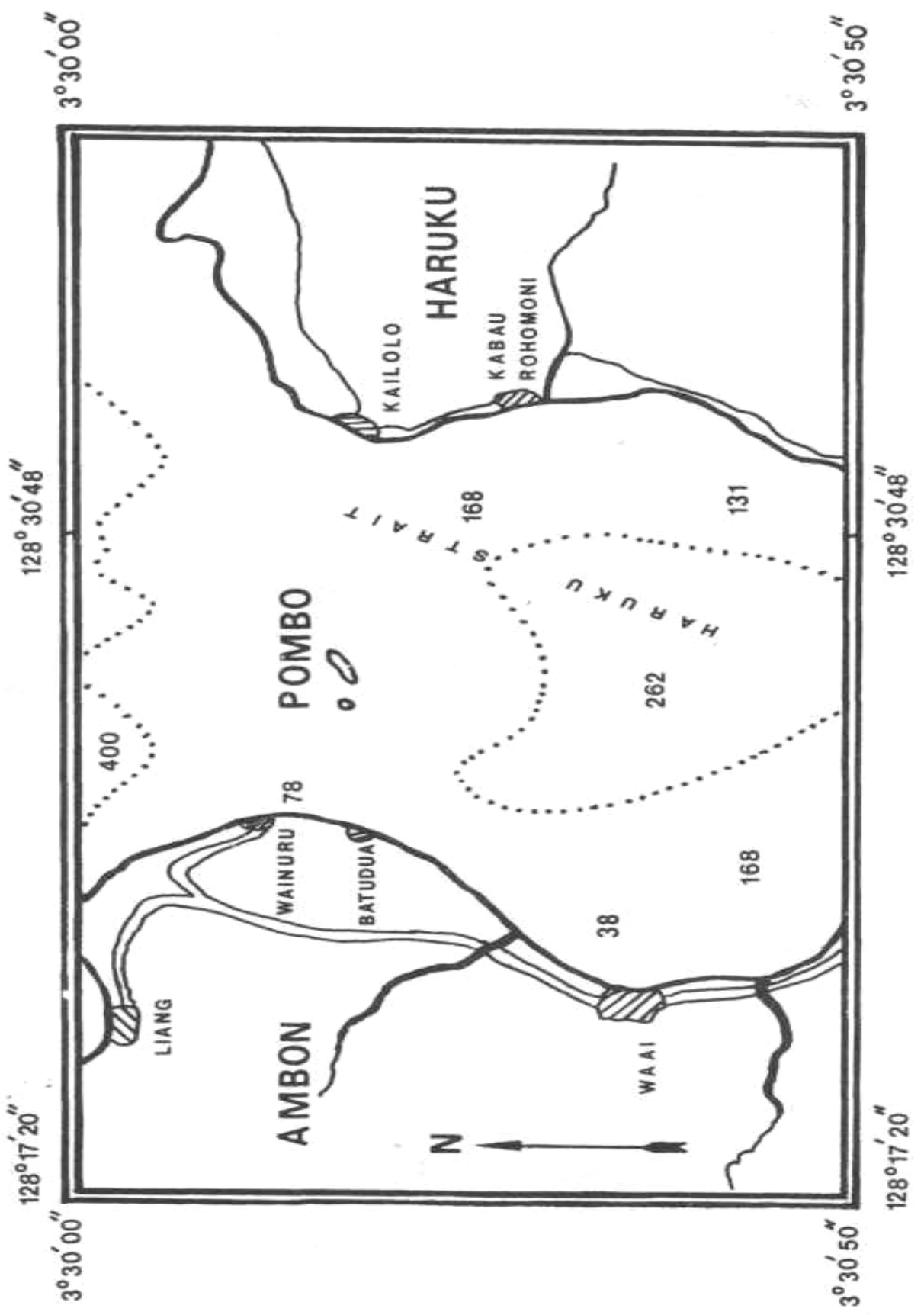

Figure 1. Pombo Island and its adjacent waters. 


\section{ONO KURNAEN SUMADHIHARGA}

The emerged part of the island consists of sand and coral limestone perhaps $1000 \mathrm{~m}$ long and $50 \mathrm{~m}$ wide with a total area of about two hectares. It appears to be $0.5-1.0 \mathrm{~m}$ above sea level. In addition, some concentrations of big trees occur particularly at the centre of the island which are mostly occupied by a wild white pigeon or "Pombo" from which ${ }^{4}$ the island gets its name. In some open clearings or under-shrubs birds, locally named Maleo (Gallus sp.), lay their eggs and bury them in the sand. On this island there is not a source of drinking water for people, so that the inhabitants are just temporary dwellers from Ambon Island and Haruku Island who work as fishermen and catch the coral fishes such as Lalosi (Caesio spp.) and Gosau ( Spratelloides delicatulus) with gillnets, beach seines, bambo traps, and explosives. All of the beach has clean white sand and shell grit. The intertidal area has white sand banks and dead coral. The northwest side is composed successively of sandy beach, Enhalus beds, and white sand.

All of the coral reefs with mostly living coral are found about $150-600 \mathrm{~m}$ offshore at depths between $1-6 \mathrm{~m}$. Further offshore, the reef flat slopes abruptly to a depth of about $20 \mathrm{~m}$, but the southeastern part is more gently sloping. The corals are mostly Porites, Acropora, and Goniopora. About one third of all the corals are dead, but this damage occurs particularly in the northwestern zone.

\section{HYDROLOGICAL CONDITIONS}

The waters surrounding Pombo Island are Piru Bay in the North and Haruku Strait in the East, South, and West. From its geographical position, it is apparent that the hydrological conditions around Pombo Island will be directly associated with those of the Banda Sea and Piru Bay. Therefore, a description of the hydrological condition of the Banda Sea and Piru Bay will, to some degree, give the hydrological account of the waters around Pombo Island. However hydrological observations have also been made in the atoll especially in the lagoon. Because of the lack of facilities, particularly of a boat, the area of investigation was limited to the lagoon.

The temperature and salinity of the lagoon from the surface down to 20 $\mathrm{m}$ is almost homogeneous. The temperature is around $28.39^{\circ} \mathrm{C}$ and the salinity is about $34.484 \%$ o. The oxygen content of the sea water shows, in the homogeneous layer, a value ranging between 3.16 to $3.84 \mathrm{ml} / \mathrm{l}$. The phosphate content of the surface water is about 0.29 ug-atom/ 1 and in the bottom water of the lagoon is about 0.45 ug-atom $/ 1$.

The direction of main current flows in the lagoon is similar to that outside the lagoon, but in the reef area the current flows in a parallel direction with the reef margin. The current velocity outside the lagoon is about 1.2 knots but in the lagoon itself is about 0.5 knot. The direction is 
north-north-east during the falling tide and south-south-west during the rising tide, that is the direction of current flow is mostly tidal-dependent. The penetration of light in the water in the lagoon reaches to the bottom at $22 \mathrm{~m}$. But outside the reef the penetration of light into the water is only $25 \mathrm{~m}$.

To give a picture of the general hydrology of the water surrounding Pombo Island, BIROWO \& ILAHUdE (1971) have shown that the Banda Sea and the Piru Bay are directly associated. The homogeneous layer in the Banda Sea and Piru Bay, whose thickness varies between $0-30 \mathrm{~m}$ and $0-100 \mathrm{~m}$, is not only characterized by homogeneous temperature within It, but also by homogeneous oxygen, phosphate, and nitrate contents. During the west monsoon, the surface salinity decreases to values between $33.00-34.00 \%$ o. In some cases the surface salinity can even drop to below $32.50 \%$ o. The temperature is around $28.0^{\circ} \mathrm{C}$ and is homogeneous down to $100 \mathrm{~m}$.

During the east monsoon, the surface salinity increases to values between 34.20 - $34.50 \%$ Meanwhile, the temperature drops to $27.0^{\circ} \mathrm{C}$ or less. It is believed that upwelling occurs in the Banda Sea during this period. Its influence is to increase further the salinity and decrease the temperature in the homogeneous layer.

The oxygen, phosphate, and nitrate contents of the sea water show that in the homogeneous layer their values are also more or less vertically constant. These values range respectively between 4.10 to $4.40 \mathrm{ml} / 1,0.05$ to 0.20 ug-atom/l, and 0.20 to 0.40 ug-atom $/ 1$.

During the west monsoon the winds are mainly from southwest direction. The sea is generally rough especially in the north of Pombo Island, though the water is relatively clear. The west monsoon drives the water from the Banda Sea to Piru Bay and as a result, strong north-northeast currents flow from Piru Bay pass Pombo Island into Haruku Strait, so that the direction of currents is against that of the wind, especially in the north of the island. Therefore, during one half of the year strong breakers and intensive water movement, especially at the reef edge of the reef sections No. 1 and No. 2, provide a favourable environment for coral growth. But this water movement can endanger the coral communities where the fine sand and coral sediments of the shallow bottoms are stirred up and make the water very cloudy. During the other half of each year, the reef regions are situated on the leeside from the south-east monsoon. Then the water is relatively calm and clear and water exchange is reduced, but strong surf occurs rather frequently especially in the reef section No. 2 and No. 4, because the current here come from north-west direction opposite to that of the winds. Therefore, an intensive water exchange also occurs during the east-monsoon in the area of section No. 2. 


\section{ONO KURNAEN SUMADHIHARGA}

\section{RESULTS}

As mentioned above the coral population at Pombo Island forms an atoll reef and for this study the atoll was subdivided into four reef sections.

The corals collected by the author within all reef sections consist of 39 species. These 39 species of living corals were located from depths of one metre to six metres (Table 1).

Table I. Coral species found in the Pombo Island coral reef

\begin{tabular}{|c|c|c|c|c|c|}
\hline \multirow{3}{*}{ No. } & \multirow{3}{*}{ S p e c i e s } & \multicolumn{4}{|c|}{ Reef section no } \\
\hline & & 1 & 2 & 3 & 4 \\
\hline & & $\begin{array}{r}\text { North } \\
\text { west }\end{array}$ & $\begin{array}{r}\text { North } \\
\text { east }\end{array}$ & $\begin{array}{r}\text { South } \\
\text { east }\end{array}$ & $\begin{array}{r}\text { South } \\
\text { west }\end{array}$ \\
\hline 1. & Psammocora togianensis (UMBGROVE) & - & - & s & - \\
\hline 2. & Pocillopora damicornis (LINNAEUS) & - & - & s & - \\
\hline 3. & Stylophora mordax (DANA) & - & ++ & ++ & ++ \\
\hline 4. & Seriatopora hystrix DANA & - & s & - & - \\
\hline 5. & Acropora concinna (BROOK) & + & - & + & + \\
\hline 6. & Acropora tubicinaria (DANA) & + & ++ & + & ++ \\
\hline 7. & Acropora symmetrica (BROOK) & s & + & + & ++ \\
\hline 8. & Acropora mauni QUELCH & $\mathbf{s}$ & + & + & + \\
\hline 9. & Acropora plicata (BROOK) & - & - & + & + \\
\hline 10. & Acropora brueggemanni (BROOK) & - & - & + & + \\
\hline 11. & Montipora striata BERNARD & $\mathbf{s}$ & - & - & - \\
\hline 12. & Cyathoseris irradians REUSS & + & + & - & + \\
\hline 13. & Pavone fromdifere LAMARCK & + & s & - & $\mathbf{s}$ \\
\hline 14. & Pavona crassa DANA & - & $\mathbf{s}$ & + & $\mathbf{s}$ \\
\hline 15. & Pavona devaricata LAMARCK & - & - & $\mathbf{s}$ & - \\
\hline 16. & Fungia fungites (LINNAEUS) & + & + & + & + \\
\hline 17. & Fungia echinata (PALLAS) & + & + & s & - \\
\hline 18. & Goniopora malaccensis BRUEGGEMANN & + & + & + & + \\
\hline 19. & Goniopora tenuidens (QUELCH) & + & s & + & ++ \\
\hline 20. & Porites nigrescens DANA & ++ & + & + & ++ \\
\hline 21. & Porites lutea MILNE-EDWARDS \& HAIME & + & + & ++ & + \\
\hline 22. & Porites andrewsi (VAUGHAN) & + & + & + & + \\
\hline 23. & Porites australiensis VAUGHAN & + & + & + & + \\
\hline 24. & Favites abdita (ELLIS \& SOLANDER) & + & + & + & + \\
\hline 25. & Falia speciosa (DANA) & + & - & - & - \\
\hline 26. & Favia pallida (DANA) & - & - & + & - \\
\hline 27. & Goniastrea retiformis (LAMARCK) & - & - & ++ & + \\
\hline
\end{tabular}


Table I (contd.)

\begin{tabular}{|c|c|c|c|c|c|}
\hline \multirow[b]{2}{*}{ No. } & \multirow[b]{2}{*}{ s p e c i es } & \multicolumn{4}{|c|}{ Reef section no } \\
\hline & & $\begin{array}{c}1 \\
\begin{array}{r}\text { North } \\
\text { west }\end{array}\end{array}$ & $\begin{array}{c}2 \\
\text { North } \\
\text { east }\end{array}$ & $\begin{array}{c}3 \\
\text { South } \\
\text { east }\end{array}$ & $\begin{array}{c}4 \\
\text { South } \\
\text { west }\end{array}$ \\
\hline 28. & Goniastrea pectinata (EHRENBERG) & - & - & $\mathbf{s}$ & + \\
\hline 29. & Hydnophora rigida (DANA) & + & + & - & - \\
\hline 30. & Hydnophora mayori HOFFMEISTER & $\mathbf{s}$ & $\mathbf{s}$ & - & - \\
\hline 31. & Echinopora lamellosa (ESPER) & - & - & - & ++ \\
\hline 32. & Echinopora horrida DANA & - & - & - & $\mathbf{s}$ \\
\hline 33. & Galaxea fascicularis (LINNAEUS) & - & s & - & - \\
\hline 34. & Plerogyra sinuosa (DANA) & - & - & + & - \\
\hline 35. & Dendrophyllia micranthe (EHRENBERG) & s & - & + & s \\
\hline 36. & Heliopora cuerulea (PALLAS) & $-\cdot$ & $\mathbf{s}$ & - & - \\
\hline 37. & Tubipora musica LINNAEUS & - & ++ & + & + \\
\hline 38. & Millepora platyphylla HEMPRICH \& EHRENBERG & - & - & + & ++ \\
\hline \multirow[t]{3}{*}{39.} & Distichopora violacea (PALLAS) & + & + & $\mathbf{s}$ & - \\
\hline & $\begin{aligned} \text { Explanation of signs: } & - \text { not found; s sporadic, } \\
& + \text { dispersed; ++ frequent, }\end{aligned}$ & $\begin{array}{l}\text { infreque } \\
\text { wide sp }\end{array}$ & & & \\
\hline & Number of coral species: & 21 & 23 & 28 & 24 \\
\hline
\end{tabular}

Of these 39 coral species, 14 species predominate by their flourishing growth, their greater number or their larger coverage within certain zones, so that they can be used as predominant species i.e. Porites with the species nigrescens and lutea; Acropora with the species tubicinaria, symmetrica, and mauni; Goniopora with the species malaccensis and tenuidens; Stylophora mordax, Goniastrea retiformis, Hydnophora rigida, Echinopora lamellosa, Tubipora musica, Millepora platyphylla, and Distichopora violacea.

Other components of the reef fauna that have been collected, consist of 56 species of molluscs belonging to 17 families, 17 species of echinoderms belonging to 10 families, 13 species of crabs belonging to 5 families and 130 species of fishes belonging to 46 families (List I - IV). Considering these animals, it is noticeable that of 56 species of molluscs, one species, Septifer bilocularis, predominates by its greater numbers; the dispersed species are Tridacna squamosa and Cypraea with the species arabica, eglantina, isabella, tigris, annulus, moneta, mappa, vitellus, carnaola, and talpa, which especially occur within the intertidal area of the reef sections No.3 \& No.4 that are exposed during low tide. Echinoids and holothuroids such as Diadema setosum and Holothuria are widespread 


\section{ONO KURNAEN SUMADHIHARGA}

within the reef. The most important commercial reef fish in Pombo Island is Spratelloides delicatulus which occurs very abundantly and is used as a livebait fish for tuna fishing. The other commercial reef fishes are often caught by gillnet such as Caesio with the species pisang, chrysozona, and erythrogaster.

Following is the detailed description of the reef section

Reef section No. 1. (Fig. 2). Along the north-western part of the atoll reef, a small barrier-like reef occurrs at about $500 \mathrm{~m}$ from the shore enclosing a lagoon. The reef flat extends about $300 \mathrm{~m}$ in width and $1300 \mathrm{~m}$ in length and declines gradually to $4 \mathrm{~m}$ deep which is exposed about $30 \mathrm{~cm}$ during an extreme low tide. The exposed reef flat, approximately ranges between $60 \mathrm{~m}$ to $200 \mathrm{~m}$ in width, is built of mostly dead coral, sand, and seaweed of Enhalus, Turbinaria and Gracillaria. However, at some places we can find small colonies of living coral especially near the fore and outer reef-edges. At the middle flat, coral growth is always endangered by extreme low tides and now is mostly damage by collectors of coral rock for the production of cement. The outer reef edge is built up of dead coral and some living coral heads with Porites lutea as predominant species. Therefore, this zone can be named "Porites lutea "and "dead coral zone". Below $4 \mathrm{~m}$ deep, this reef passes into an abrupt outer slope approximately $20 \mathrm{~m}$ deep.

The fore reef-edge is built of small colonies of living coral patches with Porites nigrescens as predominant species. It passes into a relatively smooth inner slope which is approximately $4 \mathrm{~m}$ deep, so that this zone can be named "Porites nigrescens" zone. However, both zones are now mostly damaged by explosives used for catching coral fishes, especially at the outer edge the living coral heads are relatively small, flattened, and often encrusted because of the influence of the surf. In consequence the remaining living coral colonies within this reef section is only approximately $37.5 \%$ of the total zone, so that the best name for the whole zone of this section may be "dead coral zone" (Table 2).

The reef surf along the outer reef edge depends on the direction and intensity of monsoon winds and therefore it is mostly strong during the west monsoon with its south-west-winds. Waves, after passing the outer reef edge, decrease gradually towards the shore so that the lagoon is mostly a zone of calm water and weak shore surf. These waves are responsible for the intensity of the water exchange within the reef flat and lagoon. For this reason conditions are optimal immediately near the fore reef edge, and we find here the most plentiful coral growth within this reef section.

Reef section No. 2 (Fig.2). - The north-eastern part has a gently sloping intertidal zone where coral patches are present among the white 
sand between $20-200 \mathrm{~m}$ offshore to a depth of about $2 \mathrm{~m}$. In front of a white sandy beach, further seaward, there is a coral reef which is about $100 \mathrm{~m}$ broad and $2-6 \mathrm{~m}$ deep. This reef is followed by a sharp drop-off to a depth of about $20 \mathrm{~m}$ and connected with the reef section No. 1 at the north. Along this reef, 23 species of corals were collected of which approximately $76 \%$ were living corals, located between $3-5 \mathrm{~m}$ deep (Table II).

Table II. Percentage distribution of the Pombo living coral reef from quadrats at various points in transects within the reef sections

\begin{tabular}{lccccc}
\hline No. & $\begin{array}{c}\text { Reef Section } \\
\text { Position }\end{array}$ & $\begin{array}{c}\text { Distance from } \\
\text { shore line } \\
(\mathrm{m})\end{array}$ & $\begin{array}{c}\text { Number of } \\
\text { species }\end{array}$ & $\begin{array}{c}\text { Percentage of } \\
\text { Living coral } \\
(\%)\end{array}$ & $\begin{array}{c}\text { Dead coral } \\
(\%)\end{array}$ \\
\hline & & & & \\
1. & North - west & $500-800$ & 21 & 37.5 & 62.5 \\
2. & North - east & $200-300$ & 23 & 76.0 & 24.0 \\
3. & South - east & $150-450$ & 28 & 77.7 & 22.3 \\
4. & South - west & $400-600$ & 24 & 70.0 & 30.0 \\
\hline
\end{tabular}

All the six frequent species were found i.e. Distichopora violacea, Tubipora musica, Hydnophora rigida, Acropora tubicinaria, A. mauni, and Stylo-phora mordax. Furthermore, there are 10 dispersed species and 7 species sporadically found (Table I). About $200-250 \mathrm{~m}$ offshore, at a depth of about $3 \mathrm{~m}$, the living Tubipora musica, Stylophora mordax, Acropora tubicinaria and soft coral zone represent the beginning of the living reef flat. Towards the open sea this zone is followed by the Distichopora violacea, Hydnophora rigida, and Acropora mauni zone at a depth of about $5 \mathrm{~m}$.

The rip current along this reef especially within the outer reef slope is very strong, so that the living corals at the outer reef slope exist only sparsely as small heads.

Reef section No. 3 (Fig. 2). - The south-eastern part has a dead coral flat in front of a white sandy beach, which becomes exposed during low tide and extends about $900 \mathrm{~m}$ long and $150 \mathrm{~m}$ to the open sea. This exposed dead coral flat has a gently sloping intertidal zone where Septifer bilocularis is abundant among the sand and rubble. Therefore, this zone can be named "Septifer bilocularis" zone. Further, about $300 \mathrm{~m}$ offshore from the later zone, we can find a coral reef with approximately $77.7 \%$ living corals. This reef is parallel to the shore-line and connected with the reef 


\section{ONOKURNAENSUMADHIHARGA}

section No. 2 at the east. The outer reef edge passes into a relatively smooth outer slope, which is approximately $6 \mathrm{~m}$ in depth. The reef section is situated in a sheltered area. The colonies of living coral within this reef section shows an increasing number of species. Twenty-eight species have been collected and more plentiful coral growth between 4-6 m deep was observed which was composed of Porites with the species lutea and nigre-scens; Goniastrea retiformis, Stylophora mordax; Acropora with the species symmetrica and mauni; Goniopora malaccensis, and Tubipora musica.

About $150-250 \mathrm{~m}$ offshore and at a depth of about $4 \mathrm{~m}$ the living Tubipora musica, Porites lutea, Stylophora mordax, Acropora symmetrica, Acropora mauni, and Goniopora malaccensis zone represents the beginning of the living reef flat. In the griddle, at about $300 \mathrm{~m}$ offshore and $5 \mathrm{~m}$ deep, soft coral is more frequent than the other part of the reef, but mostly dispersed in the whole area investigated. Within this zone, besides the soft coral, numerous Goniastrea retiformis are remarkable. Therefore, it is correct to characterise this zone as the "Goniastrea retiformis and soft coral" zone.

Close to the reef slope at about 400 - $450 \mathrm{~m}$ offshore and at a depth of about $6 \mathrm{~m}$ there are three predominant species i.e. Porites nigrescens, Goniastrea retiformis, and Stylophora mordax, so that this zone can be named after these species. The reef surf along this section depends somewhat on the direction and intensity of monsoon winds, but it is mostly not strong here.

Reef section No. 4 (Fig. 2). At the south-western part, the intertidal area has white sand banks, shell grit and dead coral flat. About $400 \mathrm{~m}$ to the open sea there is a wide reef flat mostly of dead coral which becomes exposed during low tide in front of a white sandy beach. This zone is densely covered by Septifer bilocularis within, so that it can be named "Septifer bilocularis" zone. This zone is followed by a gently sloping coral reef with approximately $70 \%$ living coral to a depth of about $6 \mathrm{~m}$ and extends $200 \mathrm{~m}$ further to the open sea to form a semicircular reef, which connects with the reef section No. 1 at the west and with the reef section No. 3 at the south. The outer reef edge slopes abruptly to a depth of about $20 \mathrm{~m}$. Along this reef 24 species of coral were collected. The greater number of species recorded in this reef section were Porites nigrescens, Acropora tubicinaria, Acropora symmetrica, Goniopora tenuidens, Echino-pora lamellosa, and Millepora platyphylla. This reef section is relatively rich in coral fauna but some areas have been damaged by user of local bamboo traps. Some $400-450 \mathrm{~m}$ offshore, at a depth of about $1-2 \mathrm{~m}$, Porites nigrescens and Acropora symmetrica are predominant. Therefore, this zone can be named the "Porites nigrescens - Acropora symmetrica" zone.

Towards the open sea this zone is followed by the "Acropora tubicinaria and soft coral" zone centering on a depth of about $3 \mathrm{~m}$ and 


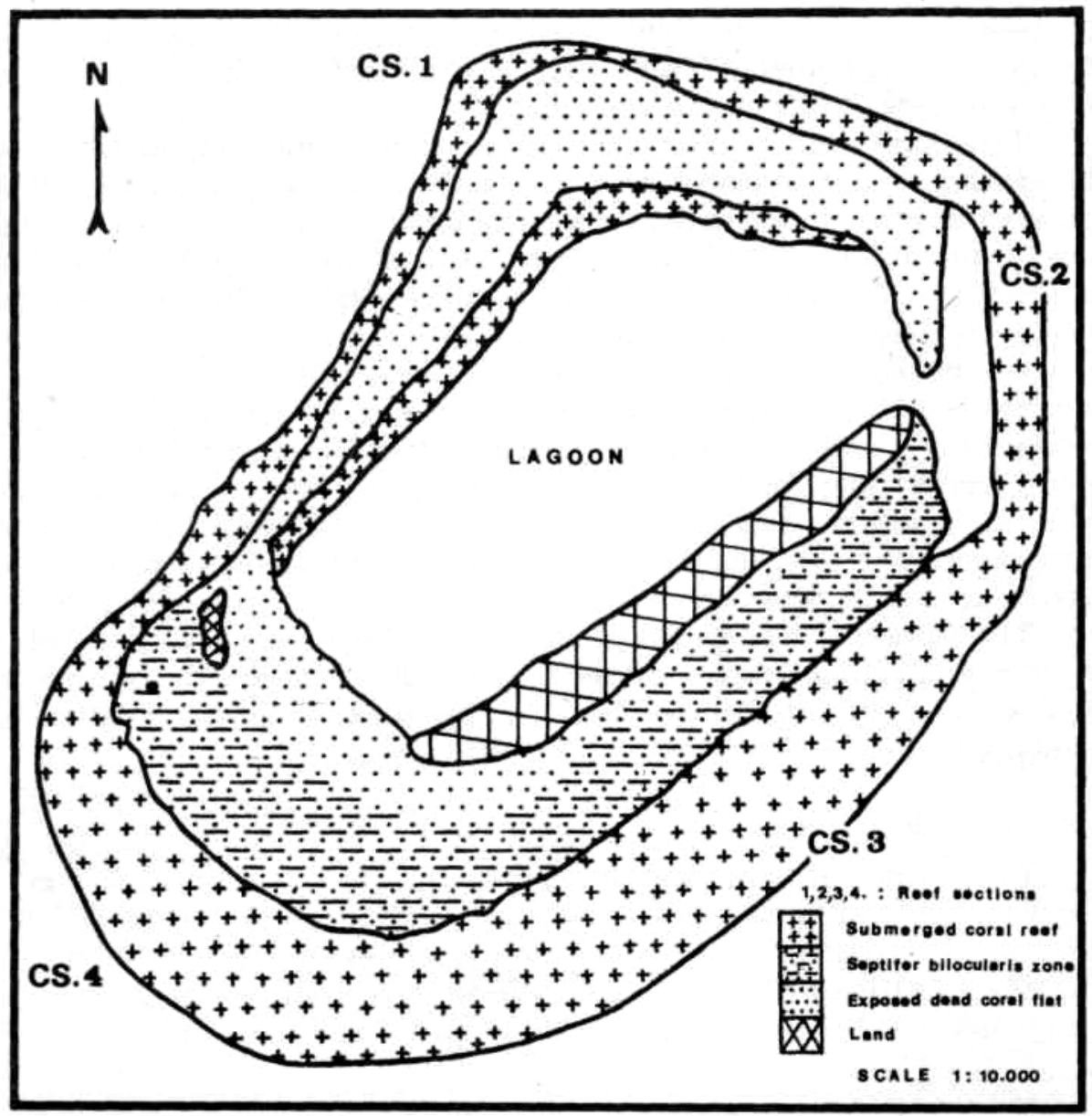

Figure 2. The coral reef of Pombo Island, with sections No. 1 - 4 .

about $500 \mathrm{~m}$ offshore. Near the reef slope at a depth of about $6 \mathrm{~m}$ and about $600 \mathrm{~m}$ offshore, all the three frequent species, i.e. Goniopora tenuidens, Echinopora lamellosa, and Millepora platyphylla were found in numerous samples. Therefore this zone can be named after the above mentioned predominant species, the "Goniopora tenuidens - Millepora platyphylla" zone.

\section{DisCUSSION AND CONCLUSION}

The results of our preliminary survey show that within the whole area investigated we found about two thirds of the corals are living and are 


\section{ONO KURNAEN SUMADHIHARGA}

composed of 39 species. Some other components of the reef fauna are present in great numbers. Therefore, the coral reef of Pombo Island seems to be a good reef for a marine garden.

The coral reef of Pombo Island becomes more important in the Moluccas because it provides good habitat for many species of commercially important reef fauna such as gosau (Spratelloides delicatulus) as live-bait fish in tuna fishing, lalosi (Caesio spp.) and bia-kuku (Septifer bilocularis) and because of its birds on the island such as pombo or pigeon and maleo (Gallus sp.) and its aesthetic values for tourism as well.

Within the reef, there exists a strict dependence of coral distribution, and growth intensity on interference by man, such as using explosives, local bamboo traps, and collecting the coral reef. This fact is especially apparent in the reef section No. 1 at the north-western part, where about two thirds of all the corals are damaged, so that this zone is named as the dead coral zone. Therefore, attention should be paid to protect the coral reef from further damage or pollution.

The following ecological factors such as bottom condition, turbidity, temperature, light intensity, and fresh water dilution have influences on the coral community and on the physiographic zonation of the coral reef of Pombo Island.

\section{Bottom condition}

Most corals can only develop on a solid surface, not on sand or mud. The water around Pombo Island has a wide solid surface bottom which is composed of coral rock about 141 hectares in extent. This is one reason why the 39 species of corals tend to form huge aggregations, because on dying, each one leaves a solid foundation on which others can develop.

\section{Turbidity}

During the west monsoon the sea at the reef edge is generally rough, because the winds and currents have contrary directions. The water offshore is relatively clear, therefore, sometimes the water is turbid, especially at the reef edge of reef section No. 1 and No. 2. For this reason we find along the lower slope as well as on the reef flat close to the outer reef edge at these sections, the species with probably low requirements for clear water, or with high tolerance to coral sand sedimentation, like the massively growing Porites and Fauites.

During the east monsoon the water is relatively calm and clear, but the intensive water exchange still occurs with all its positive consequences on coral growth. In both monsoons the reef section No. 3 is in a sheltered area where turbidity is usually low. Here we find the greatest species diversity. 
Temperatures and light intensity

According to SEARLE (1956) the other main features limiting coral growth are water temperatures below $22^{\circ} \mathrm{C}$ and low light intensity. From the hydrological data it is clear that the water temperatures in the coral reef of Pombo Island are around $27.0-28.0^{\circ} \mathrm{C}$. At the time of our investigations, the light penetration of water was about $20-25 \mathrm{~m}$. The hermatypic coral has optimum growth in water temperatures between 25 - 29 ${ }^{\circ} \mathrm{C}$. (Wells 1967). Therefore, temperature conditions are favourable for growth of these corals in the coral reef of Pombo Island.

\section{Freshwater dilution}

Excessive dilution of the sea with freshwater will also kill corals. There are two small river near Waai in Ambon Island about 3.5 miles southwest of Pombo Island. These rivers enter Haruku Strait (Fig. 1) and their freshwater masses drift and mix together with the sea water which flows southwards to the open Banda Sea through Haruku Strait. Therefore, the influence of freshwater dilution that comes from these rivers can be neglected. This fact is apparent in the coral reef of Pombo Island that the surface salinity during the whole year is always high with values ranging between 32.50 - 34.50 parts per thousand.

The zonation-of the reef sections, except for the reef section No. 1, is difficult to assess within the whole area investigated, because the different zones as found in section No. 1 are not exactly limited from each other in the other sections and the distributions of dominant coral species overlap each other. Therefore, a better characterization for the whole reef can be achieved by using the names of overlapping predominating species. It is evident that, even at the physiographic outer reef edge there are considerable differences in the dominant species in clearly recognizable "outer edge" zones.

Since we consider Pombo Island is a good environment for coral growth or a marine garden, attention should also be paid to take preventive steps against pollution.

Finally we suggest that any further investigation in the coral reef of Pombo Island should be executed to obtain more comprehensive references on considerations of the conservation and development of marine garden.

\section{ACKNOWLEDGEMENT}

The author are grateful to Dr. J.W. BRODIE (UNESCO), Dr. S. SOEMODI HARDJO (NIO) and Mr. M.K. MOOSA (NIO) for their valuable corrections of the manuscript and also to all colleagues for their good cooperation in obtaining the data. 


\section{ONO KURNAEN SUMADHIHARGA}

Finally I want to express my gratitude to Dr. A. Soegiarto (NiO), Mr. K. ROMIMOHTARTO (NIO), Mr. S. BIROWO (NIO) and Mr. ATJEP SUWARTANA (Ambon Research Station, NIO) who have encouraged me during the early stages of the International Symposium on the Ecology and Management of Some Tropical Shallow Water Communities in Jakarta.

\section{BIBLIOGRAPHY}

BIRowo, ABBOT, R.T. and H.S. ZIM 1962. Seashells of the world. Golden Press. New York : 160 pp.

S. AND A. G. ILAHUDE 1971. General hydrological conditions around Ambon Island. In : Preliminary report on Ambon survey. Mar. Res. Indonesia : 11-14.

ChILD, J. 1974. Australian sea shells. Periwinkle. Melbourne : 80 pp.

HoffMeister, J.E. 1925. Some corals from American Samoa and the Fiji Islands. Dept. Mar. Biol.Car. Inst. Washington, vol. XXII : 83 pp.

JANGOUX, M. and SuKARNO. 1974. The echinoderms collected during the Rumphius Expedition I. Oseanologi di Indonesia 1 : 36-38.

Johannes, R.E. 1970. Coral reefs and pollution. Report prepared for FAO Technical Conference on Marine Pollution, Rome.

Mergner, H. and G. SCHEER 1974. The physiographic zonation and the ecological conditions of some South Indian and Ceylon coral reefs. Proc. Symp. Corals and Coral reefs 2. Great Barrier Reef Committee Brisbane.

Munro, I.S.R. 1967. The fishes of New Guinea. Dept. Agr. Stock. Fish. Port Moresby. New Guinea : 650 pp.

Odum, P.E. 1971. Fundamentals of ecology. Third edition. W.B. Sounders Company. Philadelphia, London, Toronto : 344-349.

ROOS, R.J. 1964.. The distribution of reef corals in Curacao. Car. Mar. Biol. Inst. vol. III. No. 40.

ROOS, R.J. 1971. The shallow water stony corals of the Netherlands Antilles. Car. Mar. Biol Inst. vo. VII, No. 99.

SAKAI, T. 1937. Studies on the crabs of Japan II. Oxystomata. Sci. Rep. Tokyo Bunrika Daigaku (B) 3 suppl. 2 : 5-165

SAKAI, T. 1939. Studies on the, crabs of Japan IV. Brachygnatha, Brachyrhyncha. Yokendo Ltd, Tokyo : 202-648.

SCHUSTER, W.H. and R.R. DJAJADIREDJA 1952. Local common names of Indonesian fishes. N.V. Penerbit W. van Hoeve, Bandung S'Gravenhages: 276 pp.

SEARLE, A.G. 1956. An illustrated key to Malayans hard corals. Malayan Nature Journal, vol. II, parts 1 \& 2. Malayan Nature Society. Caxton Press. Kuala Lumpur.

SERENE, R. 1968. The Brachyura of the Indo West Pacific region. In : "Prodromus for a checklist of the non-planctonic marine fauna of South East Asia". Singapore Nat. Acad. Sci. Spec. Publ. (1): 32-120.

Smith, F.G.W. 1948. Atlantic reef corals. Univ. Miami: 122 pp.

UMBGROVE, J.H.F. 1928. De koraalriffen in'de Baai van Batavia. Watenschapelijke Mededielingen van den Dienst van den Mijnbouw, Bandung No. 7 : 68 p.

VERWEY, J. 1929. Depth of coral reefs and penetration of light, with notes on oxygen consumption of corals. Fourth Pac. Sci. Cong. Bandung : 1-23.

WEBER, $M$ and L.F. DE BEAUFORT 1913. The fishes of the Indo-Australian Archipelago. E.J. Brill. Leiden, vol. 2 : 404 pp. 


\section{APRELIMINARY STUDY ONTHEECOLOGY}

Wilson, B.R. and K. Gillett 1971. Australian Shells. A.H. \& A.W. Reed. Sydney, Melbourne, Wellington, Auckland : $168 \mathrm{pp}$.

WELLS, J.W. 1967. Scleractinia. In : Treatise on invertebrate palaeontology. Part F. Coelenterata. Edited by R.C. Moore. Qeol. Soc. America and University of Kansas Press : 328-443.

YONGE, CM. 1963. The biology of coral reefs. Adv. Mar. Biol. 1 : 209-260.

YoNGE, CM. 1973. The nature of reef-building (Hermatypic) corals. Coral reef Project. Papers in memory of Dr. Thomas F. Goreau. l., Bull. Mar. Sci. 23 (1) : 1-15. 
ONO KURNAEN SUMADHIHARGa

\section{LIST I}

THE MOLLUSCS COLLECTED IN POMBO ISLAND

\section{HALOTIDAE}

Haliotis varia LnNAEUS

Haliotis asinina LINNAEUS

TROCHIDAE

Trochus fenestratus GMELIN

Trochus niloticus LINNAEUS

Trochus lineatus LAMARCK

Trochus sp.

TURBINIDAE

Turbo argyrostomus LINNAEUS

Turbo sp.

Angaria delphinus LinNaEUS

CERITHIDAE

Rhinoclavis vertagus LINNAEUS

Cerithium aluco A.ADAMS

Cerithium fasciatum BRUGUIERE

Cerithium sp.

STROMBIDAE

Lambis lambis LINNAEUS

Lambis chiragra LINNAEUS

Strombus gibberulus LINNAEUS

Strombus variabilis SWAINSON

Strombus luhuanus L INNAEUS

Strombus aurisdiance LINNAEUS

Strombus sp.

CYMATIDAE

Charonia tritons LINNAEUS

Cabestana sp.

Distorsio anus LINNAEUS

MURICIDAE

Chicoreus ramosus LINNAEUS

Chicoreus sp.

Murex haustellum LINNAEUS

THAIDINIDAE

Drupa morum RODING

Drupa ricinus L INNAEUS
FASCIOLARIIDAE

Pleuroploca filamentosa RoDING

\section{CYPRAEIDAE}

Cypraea arabica LINNAEUS

Cypraea eglantina DUCLOS

Cypraea isabella LINNAEUS

Cypraea tigris LinNaEUS

Cypraea annulus LiNNAEUS

Cypraea moneta LINNAEUS

Cypraea mappa LINNAEUS

Cypraea vitellus LINNAEUS

Cypraea carneola LINNALUS

Cypraea talpa LinNaEUS

VASIDAE

Vasum turbinelum LiNNAEUS

MITRIDAE

Mitra mitra LinNAEUS

Mitra eremitarum RoDING

Vexillum vulpecula LINNAEUS

Vexillum rugosum GMELIN

Swainsonia casta GMELIN

CONIDAE

Conus virgin Linnaeus

Conus arenatus BRUGUIERE

Conus ebraeus LINNAEUS

Conus marmoreus LINNAEUS

Conus capitanius LINNAEUS

Conus miles LinNaEUS

PTERIIDAE

Pinctada margaritifera LINNAEUS

Pteria penguin RODING

TRIDACINIDAE

Tridacna squamosa LAMARCK

MYTILIDAE

Septifer bilocularis LINNAEUS

PECTINIDAE

Spondylus sp. 
A PRELIMINARY STUDY ON THE ECOLOGY

LIST II

THE ECHINODERMS COLLECTED IN POMBO ISLAND

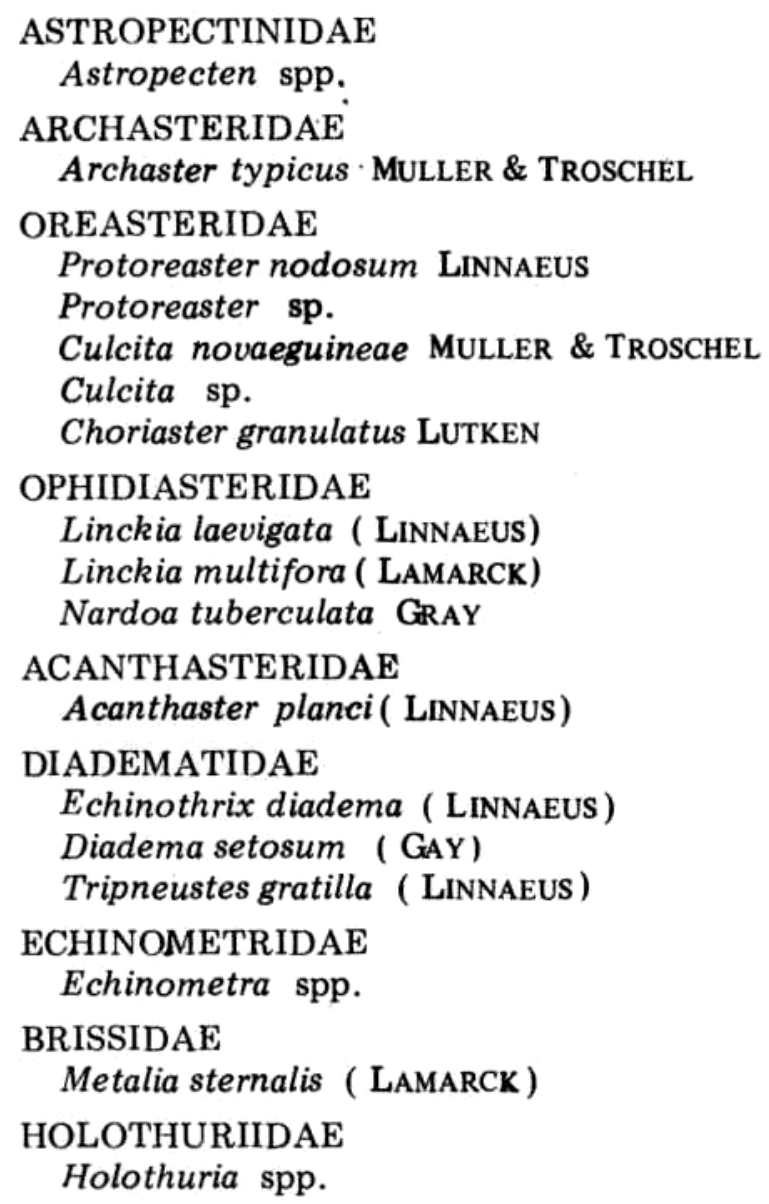


A PRELIMINARY STUDY ON THE ECOLOGY

LIST IV

FISHES COLLECTED IN POMBO ISLAND

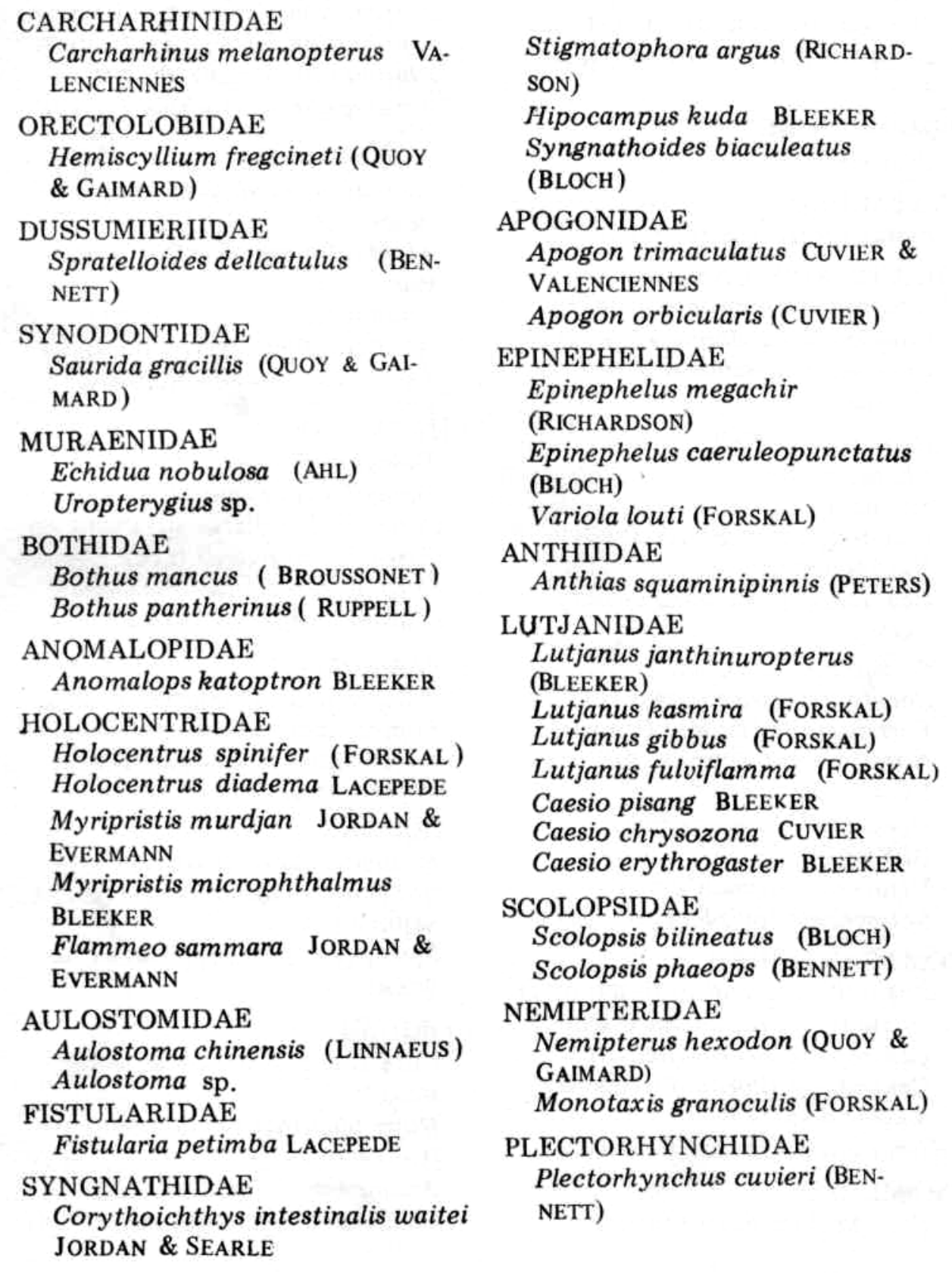


ONO KURNAEN SUMADHIHARGa

$\begin{array}{lc}\text { LETHRINIDAE } & \text { AMPHIPRIONIDAE } \\ \text { Lethrinus nebulosus (FORSKAL) } & \text { Amphiprion ephippium (BLOCH) } \\ \text { MULIDAE } & \text { Amphiprion perideraion BLEEKER } \\ \text { Upeneus trifasciatus (LACEPEDE) } & \text { Amphiprion clarkii (BENNETT) } \\ \text { Parupeneus macronemus (LACE- } & \text { Amphiprion melanopus BLEEKER } \\ \text { PEDE) } & \text { Amphiprion percula (LACEPEDE) } \\ \text { PEMPHERIDAE } & \text { Amphiprion biaculeatus (BLOCH) } \\ \text { Pempheris sp. } & \text { ABUDEFDUFIDAE } \\ \text { PLATACIDAE } & \text { Abudefduf xanthurus FOWLER \& } \\ \text { Platax orbicularis (FORSKAL) } & \text { BEAN } \\ \text { CHAETODONTIDAE } & \text { Abudefduf sexfasciatus (LACE- } \\ \text { Chaetodon unimaculatus BLOCH } & \text { PEDE) } \\ \text { Chaetodon vagabundus LINNAEUS } & \text { Abudefduf curacao (BLOCH) } \\ \text { Chaetodon melanotus BLOCH \& } & \text { Abudefduf leucogaster (BLEEKER) } \\ \text { SEHNEIDER } & \text { Abudefduf assimilis (GUNTHER) } \\ \text { Chaetodon kleinii BLOCH } & \text { CHROMIDAE } \\ \text { Chetodon meyeri BLOCH \& } & \text { Dascyllus aruanus (LINNAEUS) } \\ \text { SCHNEIDER } & \text { Dascyllus reticulatus (RICHARDSON) } \\ \text { Chaetodon triangulum CUVIER } & \text { Chromis dimidiatus (KLUNZINGER) } \\ \text { VALENCIENNES } & \text { Chromis marginatus BLOCH } \\ \text { Chaetodon trifasciatus MUNGO- } & \text { Chromis ternatensis (BLEEKER) } \\ \text { PARK } & \text { Chromis caeruleus (CUVIER) } \\ \text { Chaetodon trifascialis } & \text { POMACENTRIDAE } \\ \text { Chaetodon auriga (FORSKAL) } & \text { Pomacentrus taeniurus BLEEKER } \\ \text { Forcipeger flavissimus (JORDAN } & \text { Pomacentrus cyanomos BLEEKER } \\ \text { \& McGROGER) JORDAN \& } & \text { Pomacentrus violaceus BLEEKER } \\ \text { EvERMANN } & \text { Pomacentrus sp. } \\ \text { Heniochus chrysostomus } & \text { LABRIDAE } \\ \text { BLEEKER } & \text { Bodianus diana (LACEPEDE) } \\ \text { Heniochus varius (CUVIER) } & \text { Bodianus mesothorax (BLOCH \& } \\ \text { Tetrachaetodon plebeius (GMELIN) } & \text { SCHNEIDER) } \\ \text { POMACANTHIDAE } & \text { Pterogagus guttatus (FOWLER \& } \\ \text { Pygoplitis diacanthus (BODDAERT) } & \text { BEAN) } \\ \text { Enxiphipops navarchus (CUVIER) } & \text { CORIDAE } \\ \text { Centropyge bicolor (BLOCH) } & \text { Coris gaimardi (QUOY \& GAI- } \\ \text { Centropyge tibicen (CUVIER \& } & \text { MARD) } \\ \text { VALENCIENNES) } & \text { Novaculichthys taeniourus } \\ \text { Genicanthus lamark (LACEPEDE) } & \text { (LACEPEDE) } \\ \text { PREMNIDAE } & \text { Anampses meliogrides GUNTHER } \\ \text { Premnas biaculeatus (BLOCH) } & \text { Cheilinus diagrammus (LACEPEDE) } \\ & \end{array}$




\section{A PRELIMINARY STUDY ON THE ECOLOGY}

Cheilinus trilobatus LACEPEDE Halichoeres hortulanus (LACEPEDE)

Thalassoma hardwickei (BENNETT)

Thalassoma hebraicum (L ACEPEDE)

Thalassoma quinquevitata (LAY \& BENNETT )

Thalassoma lunnare (LINNAEUS)

Macropharyngodon meleagris

(V ALENCIENNES )

Stethojulis phekadopleura (BLEEKER )

SCARIDAE

Xanothon oktodon (BLEEKER)

Leptoscarus vaigiensis (QUOY \& GAIMARD )

CERRHITIDAE

Paracerrhites forsteri (BLOCH \& SCHNEIDER )

PARAPERCIDAE

Parapercis hexaphthalma (CUVIER)

Parapercis clathrata OGILBY

BLENNIDAE

Blennius fasciatus BLOCH

Halmablennius meleagris

(VALENCIENNES)

ZANCLIDAE

Zanclus canescens LINNAEUS

ACANTHURIDAE

Paracanthurus hepatus (LIN-

NAEUS )

Acanthurus nigrofuscus (FoR-

SKAL )

Acanthurus lineatus (LIN-

NAEUS )

Zebrasoma scopas (CUVIER)

SCORPAENIDAE

Scorpaenopsis gibbosa (BLOCH

\& SCHNEIDER)
Pterois antenata $(\mathrm{BLOCH})$

SYNANCEIIDAE

Inimicus didactylus (PALLAS)

ECHENEIDAE

Echeneis naucrates LINNAEUS

DIODONTIDAE

Diodon holacanthus LIN.

NAEUS

CANTHIGASTERIDAE

Canthigaster bennetti (BLEE-

KER)

TETRODONTIDAE

Arothron immaculatus (BLOCH

\& SCHNEIDER )

Arothron nigropunctatus

(BLOCH \& SCHNEIDER)

BALISTIDAE

Balistapus undulatus (MUNGO-

PARK)

Balistapus conspicillum (BLOCH \& SCHNEIDER)

Odomus niger (RUPPELL)

Rhinecanthus verrucosus (LIN-

NAEUS)

Melichthys vidua (RICHARDSON)

Sufflamen chrysoptera (BLOCH

\& SCHNEIDER )

Hemibalistes chrysopterus

(BLOCH \& SCHNEIDER )

Hemibalistes sp.

ALUTERIDAE

Osbeckia scripta (FORSTER)

OSTRACIIDAE

Ostracion meleagris SHAW

Ostracion tuberculatum L IN-

NAEUS 